\title{
WHAT SHALL WE CALL EACH OTHER? PART ONE: THE ISSUE OF SELF-DESIGNATION IN THE PASTORAL EPISTLES ${ }^{1}$
}

Paul Trebilco

\begin{abstract}
Summary
This paper discusses, in two parts, the 'self-designations' for their readers which were used by the authors of the Pastoral Epistles (here in part one), the Johannine Letters and Revelation (to follow in part two). Different ways in which self-designations might relate to terms coined by outsiders are considered in the introduction. It is argued that the term 'Christian' was an 'outsider-coined' term, which does not seem to have been regularly used for the purposes of self-designation in the literature considered here. The key terms used for self-designation in the Pastoral Epistles are 'brother and sister' and 'the believers', which, it is argued here, are used both by the author and the readers. Reasons why these particular self-designations were used are offered. Comparative conclusions will follow the investigation of self-designation in the Johannine Letters and Revelation in Part Two.
\end{abstract}

\section{Introduction}

Members of groups tend to develop 'names' or 'self-designations' that they use for one another. Within the group that became popularly known as 'the Quakers', the terms 'Children of the Light', 'Friends in the Truth' or 'Friends' became the preferred 'self-designation'. by members of the group themselves. ${ }^{2}$ Thus George Fox wrote of 'a

\footnotetext{
1 An earlier version of this paper was given as the Tyndale New Testament Lecture in July 2001. 'Part Two: The issue of self-designation in the Johannine Letters and Revelation' will appear in the next issue of the Tyndale Bulletin.

2 The term which was used earliest was 'Children of the Light'; soon after 'Friends' was used; see W.C. Braithwaite, The Beginnings of Quakerism (Second edition revised by H.J. Cadbury; Cambridge: CUP, 1955), 44, 131-32. He notes (pp. 131-32) 'how carefully Friends had avoided describing themselves by terms
} 
meeting of Friends' in a town near Derby, and went on to say with regard to the Vale of Beavor that, 'the mighty power of God was there also in several towns and villages where Friends were gathered.'3 However, outsiders came to call the group 'Quakers' ${ }^{4}$

What terms were used within earliest Christianity in this way to designate other members of the group? How did authors refer to members of the communities to whom they were writing, and how would these members have referred to each other? This is the issue we will address here.

We need to distinguish between three different sorts of terms. Firstly, there is 'insider language' for self-designation; that is, the term or terms that would be used to designate other members of the group when speaking strictly within the group. Secondly, there is 'outfacing language'; that is, the terms that would be used to designate members of the group when addressing outsiders, or to represent oneself to outsiders. Thirdly, there is 'outsider-coined' language;' that is language used by outsiders to designate a group. Such language is often derogatory and may begin as a nickname. Sometimes such names may be the same as either of our first two categories (particularly since a group may eventually adopt for itself a term coined by others), though they may also be different. 6

Connected to this issue of self-designation are wider issues of group identity. For terms of self-designation used by a group to

with a denominational meaning. Their own names, of which the chief were "Children of the Light" and "Friends in the Truth," or "Friends," belonged equally to all disciples with a living experience of Christ, and were not descriptive terms that would be naturally accepted or used by others.' This was because they saw themselves as a movement for all and not as a sect. Note also a letter by 'Aldam to Friends' in 1652 (quoted in Braithwaite, The Beginnings of Quakerism, 73): 'Our Friends are driven in union more close together'.

3 See J.L. Nickalls (ed.), The Journal of George Fox (Cambridge: CUP, 1952), $26,28$.

4 The name 'Quakers' was a derisive nickname probably based on 'the trembling of Friends under the powerful working of the Holy Ghost' (Braithwaite, The Beginnings of Quakerism, 57). H.L. Ingle notes that a justice named Gervase Bennett applied the name 'Quaker' to Fox and his followers and that Fox took umbrage to the label. He goes on "Fox preferred the name "Children of the Light," a phrase that he claimed Christ had bestowed on them and that they used for many years. He was creative in adopting other acceptable terms, such as "People of God," "Royal Seed of God," or "Friends of the Truth," the latter winning favor and becoming the basis of the modern name, "Religious Society of Friends." First among Friends. George Fox and the Creation of Quakerism (New York; Oxford: OUP, 1994), 54.

5 I am grateful to John Barclay for suggesting this, and the previous term.

6 The term 'Quaker' is a classic example of our third category of 'outsidercoined' language. 
represent itself, both to insiders and to outsiders, provide an important indicator of the nature of the group. ${ }^{7}$

To limit the scope of this discussion, we will look firstly at the Pastoral Epistles, and then, in part two, at the Johannine Letters and Revelation. I will focus on these particular documents because they provide contrasting evidence, but also because they are connected with Western Asia Minor, and Ephesus in particular (although the connection is not crucial to our discussion). ${ }^{8}$ They therefore add a helpful geographical focus to our enquiry. Did particular terms emerge in this area, or do we see a diversity of terms used for selfdesignation?

Accordingly, we will ask what terms do the authors of these books use, both as insider language and out-facing language, in order to designate readers as 'Christians'? Further, can we discern from what the authors say anything about the terms for self-designation (as both insider language and out-facing language) that the readers of these books used? And can we discern anything about what names outsiders used for these readers-our third category above of 'outsider-coined language'?

\section{The name 'Christian'}

Does the name 'Christian' provide an answer to our question? Would the readers of the Pastorals, the Johannine Letters and Revelation have known and used it? If so, in what way? We will argue here that the name 'Christian'9 seems to have been used in Antioch, for example, by outsiders for those within the 'Christian' group, and so comes into our third category of 'outsider-coined language'. It may be that readers of the Pastorals, the Johannine Letters and Revelation would have been known by outsiders by this term. Further, while the term may have been used by these readers to designate themselves to

7 J.H. Elliott notes that one feature of the self-definition of a group is the 'Use of collective terminology once applied to Israel or drawn from the sacred tradition', What Is Social-Scientific Criticism? (Guides to Biblical Scholarship; New Testament Series, Minneapolis: Fortress, 1993), 113. Similarly, D.G. Horrell describes $\alpha \delta \varepsilon \lambda \phi o ́ s$ as 'a basic identity-designation of those who are members of

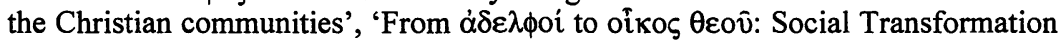
in Pauline Christianity' JBL 120 (2001) 293-311, here p. 300.

8 In my forthcoming book, The Early Christians in Ephesus from Paul to Ignatius, I will argue for this connection with Ephesus, and will draw wider conclusions from this study.

9 We will need to continue to use the term 'Christian' for convenience. 
outsiders and so could be an example of 'out-facing language' (our second category), we have no explicit evidence for this. But we will argue that it is not the term that they would have used as 'insider language' to designate other members of the group when speaking strictly within the group.

The name 'Christian' occurs in the NT only in Acts 11:26, 26:28 and 1 Peter 4:16, although it is also found in Pliny the Younger (around $112 \mathrm{CE}$ ), Tacitus (in $115 \mathrm{CE}$ ) and Suetonius (before 130).10 The crucial verse is Acts 11:25-6:

Then Barnabas went to Tarsus to look for Saul, and when he had found him, he brought him to Antioch. So it was that for an entire year they met with the church and taught a great many people, and it was in Antioch that the

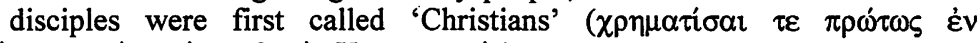

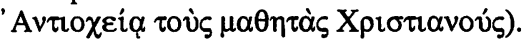

According to Luke then, the name 'Christian' originated in Syrian Antioch. But can we say when people at Antioch were first called 'Christians'? It is possible that Luke is reflecting actual chronology at this point, and so the term's use in Antioch may date back to around 44 CE. ${ }^{11}$ However, although Luke seems to imply this, as Mattingly comments: 'we are not bound to press his [Luke's] allusion chronologically. He may simply have introduced it at the most suitable place in his narrative.' 12

But it is generally agreed that the name 'Christian' was first coined by outsiders and, at least at first, comes firmly into our third category. ${ }^{13}$ There are three reasons for arguing that the name 'Christian' was an example of 'outsider-coined language'. Firstly, if it was used as 'insider language' for purposes of self-designation within the group by 'Christians' we would expect it to be found more often in the NT. Secondly, the infinitive ' $\chi \rho \eta \mu \alpha \tau i \sigma \alpha$ ', used by Luke in Acts 11:26 is best translated as 'were called' Christians, indicating

10 Pliny, Epistles 10.96; Tacitus, Annals 15.44; Suetonius, Nero 16.2 (for the date see B.H. Warmington, Suetonius: Nero. Text, with introduction and notes (Bristol: Bristol Classical Press, 1977), 3-4); see also Lucian, Alexander 25, 38; Peregrinus 11, 12, 13, 16. C.K. Barrett notes that it seems probable that the name was used in Pompeii in a graffito between 62 and $79 \mathrm{CE}$ (CIL 4.679), A Critical and Exegetical Commentary on the Acts of the Apostles; Two Volumes (ICC; Edinburgh: T \& T Clark, 1994, 1998), 556.

11 See J.H. Elliott, 1 Peter. A New Translation with Introduction and Commentary (Anchor Bible; New York: Doubleday, 2000), 790. Agrippa is mentioned in Acts 12:1 and he reigned from 41-44 CE.

12 H.B. Mattingly, 'The Origin of the Name Christiani.' JTS ns 9 (1958) 26-37, here p. 26.

13 See for example Barrett, Acts of the Apostle, 556-7; Elliott, 1 Peter, 789-91. 
that, as far as Luke was concerned, the name originated with

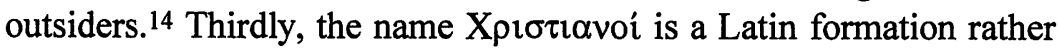
than being of Greek or Aramaic origin; this, together with the two preceding points makes it unlikely that it was first created by 'Christians'.15

We can also suggest that the name 'Christian' was coined as a derogatory name. In Acts 26:28 Agrippa uses it with a mocking sense, and in 1 Peter it is used in an outsider-facing situation with reference to persecution and again has a clearly pejorative meaning. ${ }^{16}$ Elliot suggests 'the label had a derogatory overtone from the outset, so that it meant, not simply "partisans of Christ," but something like "Christlackeys," shameful sycophants of Christ, a criminal put to ignominious death by the Romans years earlier'. ${ }^{17}$ Further, Roman sources indicate that the label Christiani had negative connotations. ${ }^{18}$

It seems likely that the name Christianoi was coined by Gentile non-Christians, because Jews would probably not call 'Christians' Xprotravoi since this would indicate acceptance of the belief that Jesus was the Messiah. ${ }^{19}$ Further, as Barrett notes 'It is a not unreasonable suggestion that it [the name 'Christian'] reflects a

14 See E. Haenchen, The Acts of the Apostles. A Commentary (Oxford: Basil Blackwell, 1971), 367-8, note 3; see also J.J. Pilch, 'Are There Jews and Christians in the Bible?' Hervormde Teologiese Studies 53 (1997) 119-125, here p. 121. This is how the verb is used in Philo (Deus. 121; Leg ad Gaius 346) and Josephus (JW 2.488; Ant 8.157; 13.318; CAp 2.30).

15 See Mattingly, 'The Origin', 27-9; Barrett, Acts of the Apostle, 556; Elliott, 1 Peter, 789-90; see also E.A. Judge, 'Judaism and the Rise of Christianity: A Roman Perspective' TynB 45 (1994), 355-68, here p. 363-4, who suggests it was coined as a political term by Latin speakers. Analogies include Caesariani, Pompeiani, Augustiani.

16 Pilch, 'Jews and Christians', 121; Elliott, 1 Peter, 791-4.

17 Elliott, 1 Peter, 790-1. E. Bickerman argues that the name was created by disciples, 'The Name of Christians' HTR 42 (1949) 109-24. However, his view that $\chi \rho \eta \mu \alpha \tau i \zeta \omega$ means 'to style oneself' is unlikely given the usage in Philo and Josephus, and in any case he admits the verb can mean 'to bear a name'; see Mattingly, 'The Origin', $28 \mathrm{n} 3$. For other views of the origin of the term see Mattingly, 'The Origin', 26-37; J. Taylor, 'Why Were the Disciples First Called “Christians" at Antioch? (Acts 11, 26)' $R B 101$ (1994) 75-94. K. Lake \& H.J. Cadbury think it is unclear whether it was coined as a derogatory name or not, The Beginnings of Christianity Part 1 the Acts of the Apostles. Vol IV English Translation and Commentary (London: Macmillan \& Co, 1933), 385. [hence: $B C$ ] 18 See Pliny, Ep. 10.96-7; Tac, Ann. 15.44; Suet, Nero 16.2; see also Elliott, 1 Peter, 791.

19 The creation of a name by non-Christian Gentiles suggests that the 'Christian' community had formed a sufficiently large and cohesive group for them to be recognized as a distinct entity, and also that they were a group which was sufficiently distinguished from the Jewish community for them to be given a different name. 
situation in which Christians were becoming numerous and were clearly distinguishable from Jews.' 20

It is very unlikely then that the term 'Christian' originated as 'insider language' used for self-designation by the early Christians and it is certainly not the term that Christians first used of each other. It is possible that it was picked up reasonably early by 'Christians' as 'out-facing language' for self-designation, and as time went on as 'insider language', since it had the advantage of focussing on

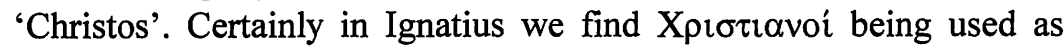
'insider language' to designate members of the groups to which he writes. Thus for example, in Eph. 11.2 he expresses his hope that he will 'be found in the lot of the Christians of Ephesus ('ंv $\kappa \lambda \eta \dot{\eta} \rho \omega$

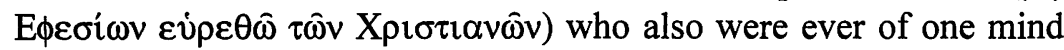
with the Apostles in the power of Jesus Christ.' Similarly in Mag. 4.1 he writes: 'It is right then, that we should be really Christians, and not merely have the name.'21 This latter passage is interesting since it shows that his addressees are known by outsiders as 'Christians' ('and not merely have the name'), but also that Ignatius used it as a selfdesignation in speaking to his readers ("we should be really Christ-

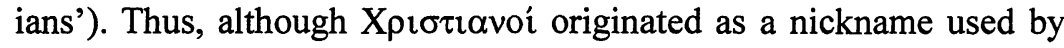
outsiders, by Ignatius' time it has become 'insider language' at least for Ignatius, but probably for some of his addressees too. ${ }^{22} \mathrm{We}$ see

20 Barrett, Acts of the Apostle, 556.

21 See also Mag. 10.1: 'let us learn to lead Christian lives'; $\operatorname{Tr}$. 6.1 'live only on Christian fare'; Rom. 3:2: 'that I may not only be called a Christian, but may also be found to be one.'; Pol. 7.3: 'A Christian has no power over himself.' It is also found in Did. 12.4: 'so that no man shall live among you in idleness because he is a Christian.' See also Diogn. 6.1-10; Mart. Pol. 3.2; 10.1; 12.1-2.

22 It may be that the name 'Christian' is accepted by the author of 1 Peter, and that its pejorative overtones in the minds of outsiders are taken as affirming a fundamental link between 'Christian' identity and suffering (see 1 Pet. 2:19-25). Thus, we could be seeing in 1 Peter the way by which a pejorative term becomes accepted as a self-designation. However, this depends on our decision with regard to a variant reading in 1 Peter $4: 16$. On the reading of $\dot{\varepsilon} v \tau \hat{\omega}$ óvó $\mu \alpha \tau \tau \tau$ ข $\tau \omega$ Peter would indeed be saying that although the name 'Christian' was used by outsiders derisively, readers should use the name gladly (as a self-designation), for that is what they are. However, J.R. Michaels (1 Peter [WBC. Waco: Word Books, 1988], 257, 269-70) puts a strong case that the original reading was $\dot{\varepsilon} v \tau \hat{\omega} \mu \varepsilon \dot{\rho} \rho \varepsilon$ $\tau o v i \tau \omega$ - 'in this matter'. (He suggests $\mu \varepsilon \varepsilon^{\prime} \varepsilon$ was original and scribes changed it to ovó $\mu$ ar under the influence of the phrase 'in the name of Christ' in v14a.) This latter reading does not suggest that readers actually used the name 'Christian' of themselves. 
then some 'leakage' between our categories-outsider-coined language becomes insider language. ${ }^{23}$

But was the term 'Christian' adopted as 'insider language' for selfdesignation by the readers of the Pastorals, the Johannine Letters and Revelation? It is the lack of usage of the name 'Christian' by Luke after Acts 11:26 and the lack of usage in the rest of the NT that is most decisive with regard to this question. If Luke used the term consistently from Acts 11 on we might feel confident that the term came to be widely used as insider language for self-designationeither in the time of which he is writing (the late 40 s to the late $50 \mathrm{~s}$ ) or at the least, by the time when he was writing. But Luke only uses the term 'Christian' once more-in Acts 26:28, which reads: 'Agrippa said to Paul, "Are you so quickly persuading me to become a Christian?"'24 Elsewhere, as we have noted, it is only found in 1 Peter 4:16.25 It is noteworthy that in both Acts $26: 28$ and 1 Peter 4:16 the focus is on outsiders, and the use of the name 'Christian' in these texts again comes into the category of 'outsider-coined language'. Secondly, as Cadbury remarks 'the absence of the word from the earliest Christian literature, including 1 Clement, and indeed from all the Apostolic Fathers except Ignatius, suggests that as a matter of fact

23 We see this sort of leakage in (the non-Christian) Lucian's Peregrinus 13, written around 165, see C.P. Jones, Culture and Society in Lucian (Cambridge, MA: Harvard UP, 1986), 117). He writes: 'Furthermore, their first lawgiver persuaded them that they are all brothers of one another after they have transgressed once for all by denying the Greek gods...'. Similarly Tertullian (Apol. 39) writes: 'And they [i.e. outsiders] are wroth with us, too, because we call each other brethren; for no other reason, as I think, than because among themselves names of consanguinity are assumed in mere pretence of affection.' (I am grateful to John Barclay for both these references.) Here Tertullian shows that outsiders knew Christians call each other 'brothers', and react to the term. Lucian, an outsider, shows this explicitly. In both examples then we see 'leakage' from one category to another-a term used by Christians ('brother', as we will see) comes to be used of them by outsiders. It is likely that other forms of transference from one category to another also occurred.

24 On the textual issues in 26:28 and its interpretation see Barrett, Acts of the Apostle, 1169-71. Luke's statement in 11:26 ('and it was in Antioch that the disciples were first ( $\pi \rho \omega \dot{\tau} \omega \varsigma)$ called "Christians") implies that there were other occurrences known to Luke when the name 'Christian' was used; see $B C$, IV.386. But the fact that he avoids using it elsewhere in Acts, apart from in 26:28, may suggest he is deliberately avoiding it. This may in turn suggest that Luke was aware that it was used in a very limited way in this early period.

251 Pet. 4:16 reads 'Yet if any of you suffers as a Christian, do not consider it a disgrace, but glorify God because you bear this name.' Mattingly ('The Origin', 27 n. 2) suggests 'The use of Christianus was clearly widespread and official when 1 Peter iv.14-16 was written', which he argues was during the reign of Trajan. But if it was widespread we would expect it to be used elsewhere in the NT. 
it was not a name early accepted by the Christians themselves.' 26 Thirdly, after Acts 11:26, Luke in fact uses a whole range of 'insider language' for self-designation for 'Christians', individually or corporately-disciples, ${ }^{27}$ brothers and sisters, ${ }^{28}$ the friends (oi

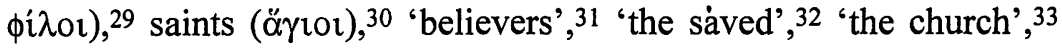
and 'the assembly'. ${ }^{34}$ This variety of self-designations strongly suggests that Luke himself did not think 'Christians' was the term used to designate other members of the group when speaking strictly within the group. It is unlikely to have been insider language for the readers of our three sets of documents then.

We have noted that the name 'Christian' originally comes into the category of 'outsider-coined language'. This, and the lack of usage in

$26 B C$ IV.386. Note that it is used in Did. 12.4, and in Diogn. 6:1-10. As noted above, Tacitus uses the term (see Tac. Ann. xv.44). This usage leads Mattingly ('The Origin', 28, 32) to think that by the time Luke wrote (sometime after 70, Mattingly is not precise), the name 'Christian' was in use among the populace, but he suggests it was also used as an official, legal term. However, although this is possible, we need to recall that Tacitus wrote early in the second century. Hence, even though he was writing about events in $64 \mathrm{CE}$, we have no way of knowing if the term 'Christian' was used in Rome in 64, although this seems likely (and is supported for example by Elliott, 1 Peter, 791). All we can say for sure is that Nero could identify a particular group as followers of Jesus at this point, but that they were called 'Christians' in 64 is not proven. Even if they were called 'Christians' in Rome at this time, that the term is not found outside Acts and 1 Peter in the NT, suggests the term was not widely used at this time elsewhere. It is not until Ignatius' writings in $111 \mathrm{CE}$ that we get the impression that the name 'Christian' is being more widely used.

27 See Acts 11:29, 13:52; 14:20, 22, 28; 15:10; 16:1; 18:23, 27; 19:1, 9, 30; 20:1, $30 ; 21: 4,16,16$.

28 See for example Acts $1: 15 ; 11: 1 ; 12: 17 ; 21: 17-18$.

29 Acts $27: 3$ is the sole occurrence.

30 Acts $9: 13,32,41 ; 26: 10$. Its use is comparatively rare. Cadbury ( $B C$ IV.380) notes 'It is, on the other hand, the usual name for Christians in the Pauline epistles. Like other terms it probably has implicit originally a possessive, "the holy ones of God." He quotes its use in 1 Enoch 37:4 as a name for the Elect'From henceforth those who possess the earth shall not be able to endure the glory of the Saints...'

31 Cadbury ( $B C$ IV.382) notes that a range of Greek expressions may be equivalent to the English term 'believers', and that these area all found sporadically in early Christians literature. He goes on (p. 382) 'None is unrepresented in Acts, but it is doubtful how far any of them are for the writer stereotyped into fixed terms.' See the range of uses in Acts $2: 44 ; 4: 32 ; 15: 5 ; 16: 1$, $15 ; 18: 27 ; 19: 18 ; 21: 20,25 ; 22: 19$. The absolute use of oi $\pi \mathrm{l} \sigma \tau$ oi occurs at $10: 45$.

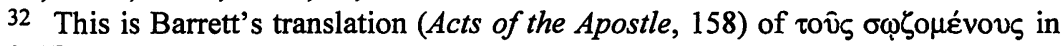
$2: 47$.

33 See for example $12: 1$.

34 See $4: 32 ; 6: 2,5 ; 15: 12,30 ; 21: 22$. On names of Christians in Acts see Cadbury

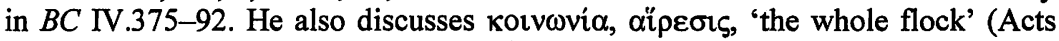

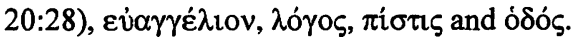


the rest of the New Testament that we have just noted, suggests that in the mid to late first century when our three sets of documents were written, the term 'Christian' was predominantly a name used by outsiders. We have also noted that originally the term 'Christian' was almost certainly a derogatory one-we can understand then why Christians did not quickly come to use it of themselves. ${ }^{35}$ Thus, even though it is found in 1 Peter, which was written to Asia Minor, its use there in a derogatory sense suggests it may not in fact have been used as 'insider language' by the readers of 1 Peter. Further, perhaps the term 'Christian' was actually used by outsiders as a name for the readers of the Pastorals, the Johannine Letters or Revelation, which are similarly written to Asia Minor, but the authors of these documents give us no hint of the term's use by outsiders. ${ }^{36}$ But that it was insider language used by the authors or readers of these three sets of documents seems very unlikely.

But we also need to note (as we will go on to show) that there are no other examples in our chosen documents of terms that we can easily recognise as being used to designate members of the group when addressing outsiders or of names used by outsiders for the group. This is probably a matter dictated by genre, since our documents are 'insider' documents. Accordingly, for the remainder of this paper, we will focus on 'insider language'-terms that would be used to designate other members of the group when speaking strictly within the group.

Before we leave Acts, one further point is worth considering. In

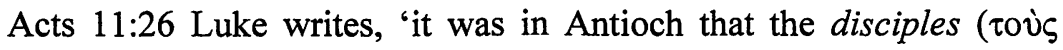

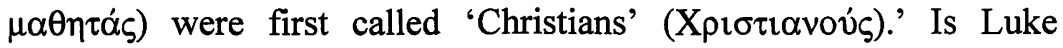
suggesting that, prior to the use of the name 'Christians', the name 'disciples' was used in some way? Was this 'insider language' of selfdesignation that was being used in Ephesus, where we think readers of our three sets of documents are located? The term $\mu \alpha \theta \eta \tau \eta \dot{ } \varsigma$ is used extensively in the Gospels, including Luke, and is found 28 times in Acts. However, $\mu \alpha \theta \eta \tau$ rn does not occur outside of the Gospels and Acts. Luke uses it in connection with Christians in Ephesus (in Acts $19: 1,9,30 ; 20: 1,30)$ but its lack of use by Paul means that its

35 Elliott (1 Peter, 791) suggests that the reason 'Christian' was only slowly adopted as a self-designation by Christians and hence is absent from most of the NT, is that the term was coined by outsiders as 'a term of opprobrium'.

36 Recall also that as we noted above, the term 'Christian' is used three times in the early second century by Graeco-Roman authors, which suggests it was used by outsiders more than our documents suggest. 
extensive use in the sections of Acts describing Paul's mission is due to Luke's penchant for the word, rather than to it probably being historical at these points. Further, 27 of the 28 occurrences of $\mu \alpha \theta \eta \tau$ ' $s$ in Acts are editorial (with it only being used by a speaker in Acts 15:10), which clearly shows that it is a Lucanism. We have no evidence then that Paul's converts in Ephesus and elsewhere, and other Christians in Ephesus too, would have described themselves as ' $\mu \alpha \theta \eta \tau \alpha i$ '. 37

So we turn then to the Pastorals, and in the second part, to the Johannine Letters and Revelation to see what these documents suggest about the sort of insider language that is used for self-designation. We will be considering what terms the respective authors used to designate other members of the group and will discuss whether these are terms the readers may have used of themselves for the purposes of self-identification. I will also seek to discuss why particular documents and the recipients of documents might use particular terms. We will also see if this investigation supports or contradicts our ongoing probing of our hypotheses-that the Pastorals and the Johannine Letters are written to different groups, whilst Revelation is written to both groups, along with other readers.

\section{Insider Terms Designating Members of the Group in the Pastoral Epistles}

In investigating the Pastorals with our question of insider language for self-designation in mind, we are immediately faced with the fact that each letter purports to be addressed to one individual. However, it is clear that these letters are intended to be read by a group, since, for example, the closing benediction in 1 Timothy 6:21 is plural: 'Grace be with you ( $\dot{\nu} \mu \hat{\omega} v)$ '. ${ }^{38}$ The plural 'we' is also used at various points (e.g. 1 Tim. 2:2; 4:10) indicating that the author has a Christian community in view and at times the author instructs 'Timothy' about

37 Luke also uses one of his favourite expressions, 'the Way' with regard to Ephesus. For example in 19:23 he says that 'no little disturbance broke out concerning the Way ( $\pi \varepsilon \rho i$ iñ $\delta \delta o \hat{)})$.' He uses the phrase 'the Way' three other times in connection with Ephesus: 'the Way of the Lord' (18:25); 'the Way of God' (18:26); 'and spoke evil of the Way' (19:9). However, the expression 'the Way' is not found elsewhere in the NT (see Barrett, Acts of the Apostles, 448) and is clearly a Lucanism. It does not seem to reflect a name for 'the Christian faith' in Ephesus in the 50s.

38 See also 2 Tim. 4:22; Tit. 3:15. 
what to say to others (e.g. 1 Tim. 4:6; 6:1-10, 17-19). Clearly therefore we may ask what the letters say about insider terms for selfdesignation of members of the community.

\section{1 'Brother and Sister': á $\delta \varepsilon \lambda \phi o ́ \varsigma$}

As with the undisputed Pauline letters, here also we find the use of the term 'á $\delta \varepsilon \lambda \phi o ́ s$ ' as a way of referring to group members. The term is found four times in this way and $\dot{\alpha} \delta \varepsilon \lambda \phi \eta \dot{~ i s ~ u s e d ~ o n c e . ~ N o t e ~ f o r ~}$ example 1 Timothy 4:6: 'If you put these instructions before the

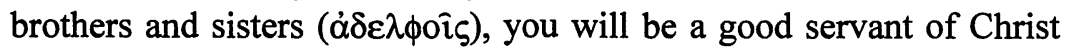
Jesus.' 392 Timothy $4: 21$, at the conclusion of 2 Timothy, is similar: 'Eubulus sends greetings to you, as do Pudens and Linus and Claudia

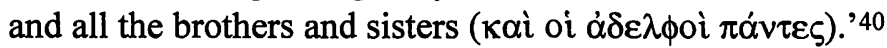

Whilst statistics can be misleading, it is worth noting that $\dot{\alpha} \delta \varepsilon \lambda \phi o ́ s$ is significantly more common in the undisputed Pauline letters than in the Pastorals. ${ }^{41}$ Whilst $\alpha \dot{\alpha} \varepsilon \lambda \phi o ́ \varsigma$ or $\alpha \dot{\delta} \varepsilon \lambda \phi \eta$ is used as a fictive kinship term to refer to other 'Christians' on average once per page of NestleAland's 26th edition of the Greek New Testament, the usage in the Pastorals is 0.28 times per page. ${ }^{42}$ Thus these two terms are used significantly less in the Pastorals than elsewhere in the Pauline corpus.

39 That the reference here is to all members of the church and not just leaders is argued convincingly by I.H. Marshall, $A$ Critical and Exegetical Commentary on the Pastoral Epistles (ICC; Edinburgh: T \& T Clark, 1999), 548-9.

40 Note that this verse shows that oi $\alpha \delta \varepsilon \lambda \phi o i$ is being used inclusively to refer to both men and women, since Claudia is clearly thought of as part of 'oi $\alpha \delta \varepsilon \lambda \phi o i$

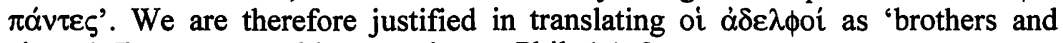
sisters'. For a comparable example, see Phil. 4:1-2.

41 On the usage of $\dot{\alpha} \delta \varepsilon \lambda \phi o ́ \varsigma$ in Paul see W.A. Meeks, The First Urban Christians (New Haven: Yale UP, 1983), 87; K.O. Sandnes, A New Family. Conversion and Ecclesiology in the Early Church with Cross-Cultural Comparisons (StzIGC 91; Bern: Peter Lang, 1994), 73-82; R. Aasgaard, "My Beloved Brothers and Sisters!" a Study of the Meaning and Function of Christian Siblingship in Paul, in Its Greco-Roman and Jewish Context' (D.Th, University of Oslo, 1998), 129-312;

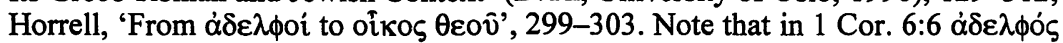
is the antonym of 'unbelievers'. See also for example Rom. 14:10, 13, 15, 21; 1 Cor. $8: 11,13 ; \mathrm{Phm}$. 16. In some passages it is clear that Jews considered themselves as a fellowship of 'brothers and sisters' or used $\dot{\alpha} \delta \varepsilon \lambda \phi o ́ s$ with the broad sense of 'compatriots' or 'fellow Jews'; see Gn. 13:8; Ex. 2:11; Lv. 25:35f; Dt. 15:3, 7, 9, 11-12; 22:1-4; Je. 22:18; 2 Mac. 15:14; Tob. 1.3, 5, 10, 16; 2:2, 3,

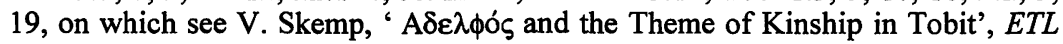
75 (1999) 92-103); Spec Leg. 2:79-80; Josephus, JW 2:122; 1QS 6:10, 22; CD $6: 20 ; 7$. von Soden (TDNT I.145) notes 'There can be no doubt, however, that $\dot{\alpha} \delta \varepsilon \lambda \phi \cos _{\varsigma}$ is one of the titles of the people of Israel taken over by the Christian community.'

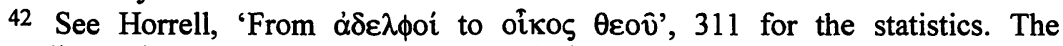
undisputed Paulines are Rom., 1 Cor., 2 Cor., Gal., Phil., 1 Th. and Phm. For 
Can we explain why the title $\alpha \delta \varepsilon \lambda \phi o ́ s$ is used in the Pastorals, but also why it is used less often than in the undisputed Paulines? In their use of the title $\alpha \delta \varepsilon \lambda \phi o ́$, the Pastorals are reflecting their links with the Pauline tradition, in which the label was very common. But why is the title $\dot{\alpha} \delta \varepsilon \lambda \phi o ́ \varsigma$ noticeably less prominent in the Pastorals than it is in the undisputed Paulines? It could be that the reduction in usage is due to the fact that these letters are said to be written to individual church leaders, rather than to communities. However, this explanation is ruled out by the fact that the short letter of Philemon has more occurrences of $\dot{\alpha} \delta \varepsilon \lambda \phi o ́ \varsigma$ than the three Pastorals together. So the nature of the addressees does not explain the decline in usage. ${ }^{43}$

We suggest firstly, that the more hierarchical pattern of leadership and group structure in the Pastorals, reflected in the development of the office of presbyter-overseers and deacons, has led to the decline in the use of $\dot{\alpha} \delta \varepsilon \lambda \phi o ́ s$, at least by the author. ${ }^{44}$ But a second and related factor that is probably also at work here is the understanding of the church as a household. As has often been noted, the analogy between the church and the household is commonly found in the Pastorals. ${ }^{45}$ But more than this, the church is regarded as the household of God, as we find in 1 Timothy 3:14-15: 'I am writing these instructions to you so that, if I am delayed you may know how one ought to behave in the household of God, which is the church of the living God, the pillar and bulwark of the truth.'

Further, it seems that the author has applied or superimposed the contemporary household model to the church, so that, in the Pastor's view, the ethos and ordering of the church should reflect the values

example, the terms are used 5 times in the Pastorals, five times in Philemon, and 39 times in 1 Cor. The total in the undisputed Paulines is 112 times; it is the term Paul uses most often to refer to members of the communities to whom he writes. The figures exclude the use of the terms to describe a biological kinship relation.

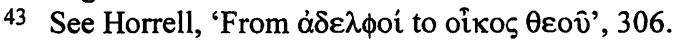

44 We are not suggesting that $\dot{\alpha} \delta \varepsilon \lambda \phi o ́ \varsigma$ does not contain some sense of hierarchy or superiority (cf. Horrell, 'From $\alpha \dot{\alpha} \varepsilon \lambda \phi o i$ to oíko $\theta \varepsilon \circ v^{\prime}, 297$ ), since clearly there were older and younger $\alpha \delta \varepsilon \lambda \phi o i$ and so there could be a sense of hierarchy in the use of the term. But the comprehensive use of the household model in the Pastorals, including the prominent place given to the male householder, reflects a

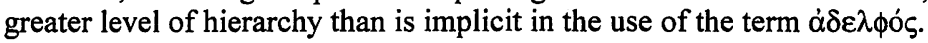

45 This analogy underlies verses such as 1 Tim. 3:4-5, 12; 5:14; 2 Tim. 2:20-1. On the household character of the church in the PE; see N. Brox, Die Pastoralbriefe (4th ed; Regensburger NT 7; Regensburg: Friedrich Pustet, 1969), 157-9; D.C. Verner, The Household of God. The Social World of the Pastoral Epistles (SBLDS 71; Chico, CA: Scholars, 1983), 127-87; Sandnes, A New

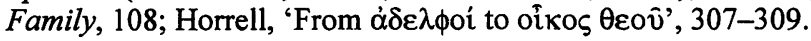


and ethos of the traditional household of the time. ${ }^{46}$ Hence I suggest that the predominant view is not that members of the 'household of God' are all regarded as 'brothers and sisters', as we see in the undisputed Paulines. ${ }^{47}$ Rather, as in the household, men are leaders and women are not, and there is a hierarchy even within the group of men-between those who are leaders and others who are not, between older men and younger men, older women and younger women. ${ }^{48}$ This means that the place of the 'father' has been reasserted, and so we get the emphasis on hierarchy within the "household of God' ${ }^{49}$ This has led, I would suggest, to a lessening of the ethos of being 'brothers and sisters' across the Christian community as a whole. ${ }^{50}$

Titus 2:2-6 represents this trend, but I think it is clearest in 1 Timothy $5: 1-2$, a passage which uses the term áde $\lambda \phi$ ós. In 1 Timothy 5:1-2 we read: 'Do not speak harshly to an older man, but speak to him as to a father ( $\pi \alpha \tau \varepsilon \dot{\varepsilon} \alpha$ ), to younger men as brothers

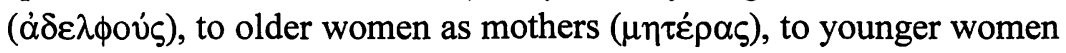

46 See for example J.M. Bassler, 1 Timothy, 2 Timothy, Titus (Abingdon NT Comm.; Nashville: Abingdon, 1996), 91, who notes 'The author of this letter, though, applies conventional advice concerning relationships among household members to the church as the household of God.' On the family in antiquity see Verner, The Household of God, 27-81; Sandnes, A New Family, 47-64; D.B. Martin, 'The Construction of the Ancient Family: Methodological Considerations', JRS 86 (1996) 40-60.

47 We are not suggesting that the Pauline communities were egalitarian (a debate

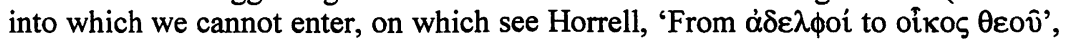
303,310 ), but rather that in the Pastorals we see a greater emphasis on hierarchical relationships than we see in the undisputed Paulines. Horrell ('From

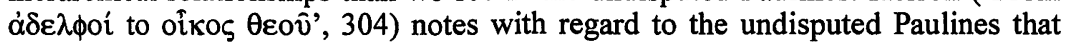
'the terms oikos and oiki $\alpha$ are never used by Paul to describe the Christian community'. Of course $\alpha \delta \varepsilon \lambda \phi o ́ s$ language, and that of the 'household' are closely

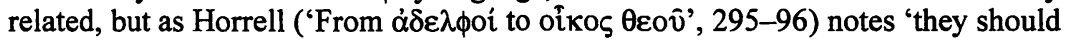
not simply be treated together as varied forms of familial terminology. We need to ... take account of the ways in which the different terms may reflect different ideals with regard to the construction of social relationships in the Christian communities.'

48 We thus get the emergence of what may be called the 'Christian hierarchical family'; see F. Young, The Theology of the Pastoral Letters (Cambridge: CUP, 1994), 89-90.

49 Verner (The Household of God, 79) notes: 'in both [Greek and Roman] societies the household was conceived of as a patriarchal institution, whose male head (кúpıos, paterfamilias) exercised sweeping, although not entirely unrestricted authority over the other members. These members fell into three main

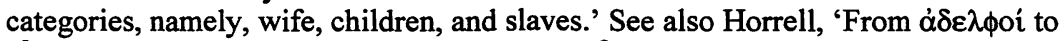
oikos $\theta \varepsilon 0 \hat{v}$ ', 297-9 who notes (298) 'when oikos is used to describe the human household it often denotes some kind of structured and stratified group.'

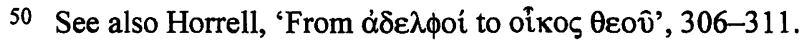


as sisters ( $\dot{\alpha} \delta \varepsilon \lambda \phi \dot{\alpha} \varsigma)$-with absolute purity. ${ }^{51}$ Here we have the metaphorical use of $\dot{\alpha} \delta \varepsilon \lambda \phi o ́ \varsigma$ but we also have the metaphorical use of 'father' and 'mother'. In particular, it is envisaged that a younger leader should speak in a very conciliatory way to one they should regard as a 'father'. Given the role and power of the 'father' in the family of the period, this clearly suggests a different style of relationship from that of two 'brothers' interacting with one another. Similarly, because of their seniority, older women are to be treated as

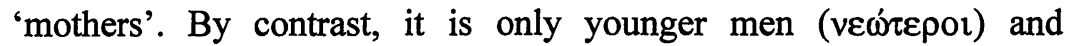

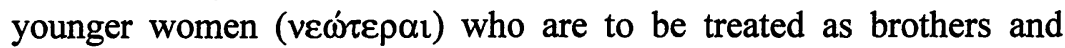
sisters respectively. Overall, relations are patterned according to seniority - probably of both age and faith. Thus, perceiving the church as the 'household of God', seems to have led to the development of an internal hierarchy, in which the church reflects to quite some degree the hierarchical relationships found in a household, rather than just being 'brothers and sisters'.52 By comparison, whilst Paul sees himself as the 'father' of the Corinthians (1 Cor. 4:16), or the Thessalonians (1 Th. 2:11) or of Timothy (Phil. 2:22) or Onesimus (Phm. 10),53 he never says that someone should be treated as a 'father'. It seems likely then that ' $\alpha \dot{\delta} \varepsilon \lambda \phi \sigma^{\prime} \zeta$ ' is fading as an insider term for self-designation in the Pastorals for reasons which can be explained by other developments which are clear in the letters.

1 Timothy $6: 2$ is also revealing in this regard. Here, it is acknowledged that both slaves and masters are ' $\dot{\alpha} \delta \varepsilon \lambda \phi o i '$ '. But rather than arguing that being ' $\dot{\alpha} \delta \varepsilon \lambda \phi o i$ ' means that the Christian slave should be treated differently from non-Christian slaves by the Christian master, the Pastor warns slaves not to 'be disrespectful $(\mu$ iे

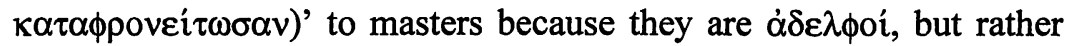
to 'serve them all the more, since those who benefit by their service are believers and beloved.' This suggests that, in the Pastor's opinion, slaves should not seek social consequences which could be claimed on

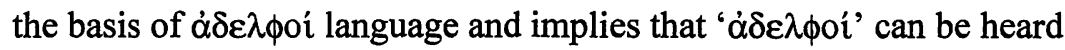

51 Compare Tit. 2:2-6, where different age groups are addressed, but $\dot{\alpha} \delta \varepsilon \lambda \phi o ́ \varsigma$ is not used. We will discuss below the only other use of $\alpha \delta \varepsilon \lambda \phi o ́ s$, which is in $1 \mathrm{Tim}$. 6:2. The advice in $1 \mathrm{Tim}$. 5:1-2 regarding attitudes to different age-groups contains conventional teaching found in popular moral philosophy; see Marshall, Pastoral Epistles, 572-73; M. Dibelius \& H. Conzelmann, The Pastoral Epistles (Hermeneia; Philadelphia: Fortress, 1972), 72 for examples.

52 Note also what is said to women (1 Tim. 2:9-15; Tit. 2:1-10) and to slaves (1 Tim 6:1-2); see also Bassler, 1 Timothy, 2 Timothy, Titus, 92. Sandnes (A New Family, 48) notes 'The household is clearly a hierarchical model with given social roles'.

53 Compare also Phil. 2:22. 
with connotations that the Pastor is not in favour of, that is, more egalitarian connotations that he thinks are inappropriate or unwise in his social context.54 Rather the Pastor is anxious to avoid the suggestion that as 'd́ $\delta \varepsilon \lambda \phi o$ ', Christian slaves should be treated differently by Christian masters. Here then we have the language of 'brother-sister', but the social practice advocated is much more akin to that of the hierarchically structured household. 55

What this also suggests is that the way in which ó $\delta \varepsilon \lambda \phi o ́ s$ language was being used in the community may have been somewhat different from the way the Pastor used it. Perhaps some slaves had been claiming that since they were $\dot{\alpha} \delta \varepsilon \lambda \phi o$ of of their masters, this should have real and practical social implications. ${ }^{56}$ For the Pastor, advocating this is to be disrespectful (1 Tim. 6:2), which clearly expresses the view of the slave owner 'from above'. This is probably not how the slaves would have put it; they probably wished 'to act in a way subversive of the master-slave relationship, treating them [masters] more like equal siblings, as $\alpha \dot{\delta} \varepsilon \lambda \phi o$ o.' 57 We can conclude two things from this. Firstly, we again see that the Pastor is not a whole-hearted advocate of ' $\alpha \dot{\delta} \delta \lambda \phi o ́ \varsigma$ ' language because of his more hierarchical views. Secondly, we can suggest that some in the community (slaves but perhaps others too) may have preferred the (more traditionally Pauline) self-designation of ả $\delta \varepsilon \lambda \phi o ́ s$ and may have used it much more frequently than the Pastor did. In this regard then, the Pastor can be seen to be prescriptive rather than simply descriptive.

\section{2 'The Believers': oi $\pi \iota \sigma \tau o$ i}

A second 'self-designation' used in the Pastorals is oi $\pi \mathrm{l} \sigma \tau$, best translated as 'the faithful ones'. In 1 Timothy 4:12 we read: 'Let no one despise your youth, but set the faithful $(\tau \hat{\omega} v \pi \mathrm{\imath} \sigma \tau \hat{\omega} v)^{58}$ an

\footnotetext{
54 Note 1 Tim. 6:1: slaves should regard their masters as worthy of all honour 'so that the name of God and the teaching may not be blasphemed.'

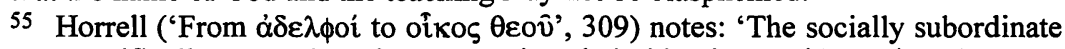
are specifically warned against expecting their identity as $\dot{\alpha} \delta \varepsilon \lambda \phi o i ́$ to have an impact on conventional social relations.' Compare Phm. 16.

56 On the basis of this passage P.H. Towner suggests 'Christian slaves at Ephesus must have been pressing for emancipation', The Goal of Our Instruction: The Structure of Theology and Ethics in the Pastoral Epistles (JSNTSS 34; Sheffield: JSOT, 1989), 175.

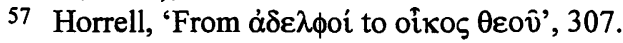

58 W.D. Mounce, Pastoral Epistles (WBC 46. Nashville: Thomas Nelson, 2000), 245 gives the translation 'the faithful' here, which helpfully ties the usage into other occurrences of the $\pi \imath \sigma \tau$ - word group in the Pastorals.
} 
example in speech and conduct, in love, in faith, in purity.' In 1 Timothy 4:3 we read of food: 'which God created to be received

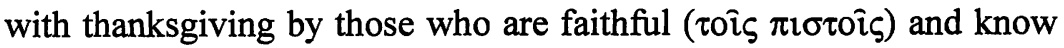
the truth.' In Titus 1:6, among the qualifications for an elder, we read: 'someone who is blameless...whose children are believers [or 'faithful

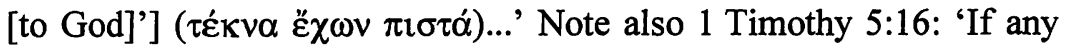
believing woman [or woman who is faithful (to God)] ( $\pi \iota \sigma \tau \grave{)}$ ) has relatives...'.59

Overall, $\pi \imath \sigma \tau$ ó $\varsigma$ is used as a term designating a member of the group (with or without the article) seven times in the Pastorals. ${ }^{60} \mathrm{It}$ is much more prominent with the meaning of 'the faithful one' or 'the believer' in the Pastorals than it is in the undisputed Paulines, where it is found with this meaning only in 2 Cor. 6:15; Gal. 3:9.61

Can we explain why the author uses oi $\pi$ iotoi as a label? We note firstly the significance of the $\pi \iota \sigma \tau$ - word group in the Pastorals.

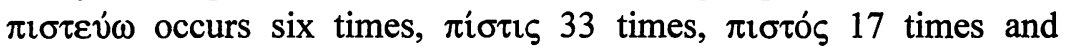
$\pi \iota \sigma \tau o ́ \omega$ once, a total of 57 occurrences. Marshall notes that this is 'a

59 Note the variant here: $\pi \iota \sigma \tau \mathrm{c} \zeta \hat{\eta} \pi \iota \sigma \tau \dot{\eta}$, but the text as given above is clearly

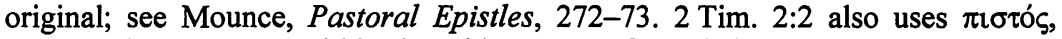
although here a group within the wider group of 'Christians' seems to be spoken of; the verse reads: 'and what you have heard from me through many witnesses

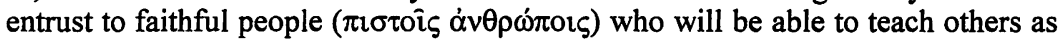
well.' The person is taught 'the faith' and then must pass this on to others who will be 'faithful' as is appropriate to holding 'the faith'. Note also 1 Tim. 6:2 and compare Tit. 2:10.

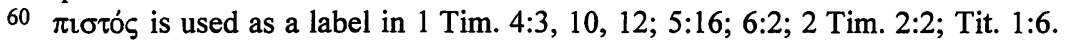
Marshall (Pastoral Epistles, 215) notes that 'in some of these cases [of the use of $\pi \imath \sigma \tau o ́ \varsigma]$ the usage is tantamount to categorising a person as "Christian".' $\pi \imath \sigma \tau$ ' $\varsigma$ is used with the meaning of 'faithful' in 1 Tim. 1:12; 3:11. In Tit. 1:9 one of the characteristics of a bishop is that 'He must have a firm grasp of the word that is

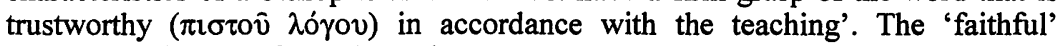

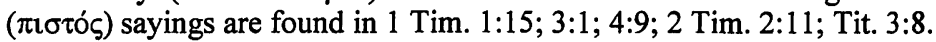

61 Eph. 1:1 and Col. 1:2 are related but different in usage of the term. A related usage is that of the verb $\pi \imath \sigma \tau \varepsilon v i \omega$ which can be used to designate the group of believers; see Cadbury in $B C$, IV.382. E.g. in 1 Tim. 1:16 we read: 'to those who

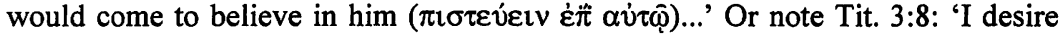
that you insist on these things, so that those who have come to believe in God (oi $\pi \varepsilon \pi \iota \sigma \tau \varepsilon v \kappa o ́ \tau \varepsilon \varsigma, \theta \varepsilon \hat{\text { ) }}$ may be careful to devote themselves to good works...' See also 1 Tim. 3:16; Tit. 3:8. This usage is reasonably common in the undisputed Paulines; see e.g., Rom. 1:16; 3:22; 4:11, 24; 9:33; 10:4, 11; 1 Cor. 1:21; 14:22. But the verb, which is used in this regard in a variety of linguistic ways, does not seem to have functioned as a 'label' in the same way as oi $\pi$ lotoi functions in the

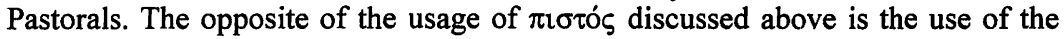
term ö $\pi \_\tau$ ○ for an 'unbeliever' who is outside the community. Note $1 \mathrm{Tim}$. 5:8; Tit. 1:15; this usage is also found in Paul; see e.g. 1 Cor. 7:12-15. Further, note that one of God's key characteristics for our author is that God is faithful; see 2 Tim. 2:11-13; this is also found in Paul; see e.g. 1 Cor. 1:9; 10:13; 2 Cor. 1:18. 
figure which is almost three times as high as one would have expected in comparison with the use of the word-group in the earlier epistles of Paul. This is a quite remarkable concentration of vocabulary, even when we make allowance for some specialized usages.' 62 Clearly, the concepts of faith, to be faithful and to believe, are of central importance to the author and it is understandable that insider language of self-designation for 'Christians' has emerged from this word group.

But secondly, we note the particular way in which $\pi i \sigma \tau \iota \varsigma$ is used in

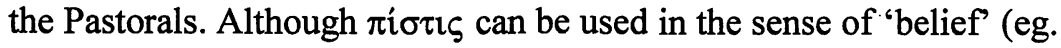
1 Tim. 2:15; 2 Tim. 3:15), in the Pastorals we find the expression ' $\eta$ $\pi i \sigma \tau \iota \varsigma^{\prime}$, 'the faith', being used regularly as a term which summarises the content of what is believed. ${ }^{63}$ For example, in 1 Timothy $1: 19$ we read that 'certain persons have suffered shipwreck in the faith ( $\pi \varepsilon p i$

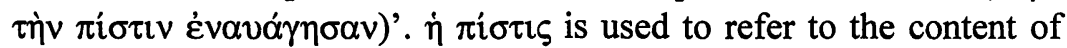
what is believed a total of 15 times.64 2 Timothy $2: 2$ is related to this, where we read that what is heard or believed, which is elsewhere in the Pastorals called 'the faith', can be passed on from one person to another. Alternative expressions for 'the content of what is believed' are 'the deposit' ( $\pi \alpha \rho \alpha \theta \eta \dot{\eta} \kappa \eta)$ which has been entrusted to a person, ${ }^{65}$ or 'the teaching $(\delta 1 \delta \alpha \sigma \kappa \alpha \lambda i \alpha)$ '. ${ }^{66}$

Given the central place of 'faith' or 'belief' in the Pauline tradition, it seems likely that words from the $\pi \iota \sigma \tau$ - group would be used as a term for self-designation in this tradition at some point. But given this general possibility, we can suggest that in the particular case of the Pastorals, the use of oi $\pi \mathrm{i} \tau$ toi as a self-designation is related to the particular significance of the $\pi \iota \sigma \tau-$ word group for the Pastor, one

62 I.H. Marshall, 'Faith and Works in the Pastoral Epistles.' SNTU 9 (1984) 20318, here p. 211; see also Towner, The Goal of Our Instruction, 121-29; Marshall, Pastoral Epistles, 213-17; Mounce, Pastoral Epistles, cxxx-cxxxii.

63 This is also found in Gal. 1:23 and perhaps 3:23-25.

64 See 1 Tim. $1: 19 ; 3: 9 ; 4: 1,6 ; 5: 8,12 ; 6: 10,12,21 ; 2$ Tim. 1:5; 2:18; 3:8; 4:7; Tit. 1:13; 2:2. Marshall (Pastoral Epistles, 214) notes that the anarthrous usage may also refer to the content of what is believed; see 1 Tim. $2: 7 ; 3: 13 ; 2$ Tim. $1: 13$. Compare also the pronounced usage of the term 'the truth'; see 1 Tim. $2: 4$, $4: 3 ; 6: 5 ; 2$ Tim. $1: 14 ; 2: 15,18,25 ; 3: 7-8 ; 4: 4$; Tit. $1: 1,14$. This latter form of usage is found in Paul; see Gal. 1:23; 1 Cor. 16:13; 2 Cor. 13:5; Phil. 1:27, but it does seem to be more pronounced in the PE.

65 See 2 Tim. 1:12-14; $\pi \alpha \rho \alpha \theta \eta \dot{\kappa} \eta$ is used in 1 Tim. 6:20; 2 Tim. 1:12, 14. On the expression see C. Spicq, 'Saint Paul et la loi des Dépôts', $R B \quad 40$ (1931) 481-502.

66 For example in Tit. 2:10. Note also the expression 'the sound words', which uses medical imagery to refer to the content of what is believed; see for example 1 Tim. 6:3; 2 Tim. 1:13; Tit. 1:9; 2:1; A.J. Malherbe, 'Medical Imagery in the Pastoral Epistles' in Texts and Testaments: Critical Essays on the Bible and Early Church Fathers (ed. W.E. March; San Antonio: Trinity UP, 1980), 19-35. 


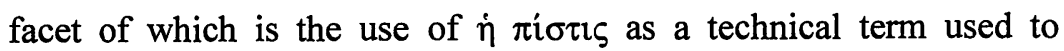
designate a body of doctrine or belief. Thus oi $\pi$ $\sigma \tau$ oi ('the faithful ones') came to be used as an insider term for one who has faith and accepts 'the faith' or lives by this body of doctrine. We see then that the distinguishing activity of the group (having 'faith') became the 'label' for the adherents to that tradition. Clearly, for this group, 'faith' is central to the formation of their 'Christian' identity, to the extent that their most prominent internal 'self-designation' was derived from this term.

\section{The Use of Other Terms}

Other terms are found as 'insider' self-designations in the Pastorals, although they are not used very often. 'The saints' is used as a label in 1 Timothy 5:10, where it is said that a widow who is put on the list must have 'washed the feet of the saints ( $\dot{\alpha} \gamma i \omega v)$ )'.67 'The elect' (oi $\dot{\varepsilon} \kappa \lambda \varepsilon \kappa \tau$ ćs) is also used as an insider name for 'Christians' in 2 Timothy 2:10: 'Therefore I endure everything for the sake of the elect'. This usage is also found in Titus 1:1: 'Paul, a servant of God and an apostle of Jesus Christ, for the sake of the faith of God's

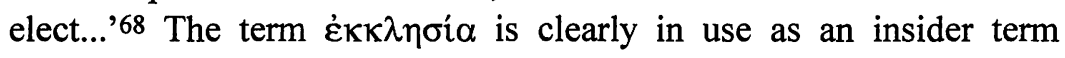
designating the group collectively, for example in 1 Timothy 3:5: 'for if someone does not know how to manage his own household, how can he take care of God's church.' 69 The author can also speak of Christians as 'a people' ( $\lambda \alpha$ ó ; Tit. 2:14) and 'the household of God', which we have already discussed, is used as a term for 'Christians' collectively in 1 Timothy 3:15.

\section{Conclusions}

We conclude then that 'brothers and sisters' and 'the believers' are most commonly used for the purpose of 'insider' self-designation in

67 Marshall (Pastoral Epistles, 595-96) notes that öros is used here of Christians in general.

68 The term is also used to refer to 'the elect angels' in 1 Tim. 5:21. There are also particular labels for individuals. As in the undisputed Paulines the term

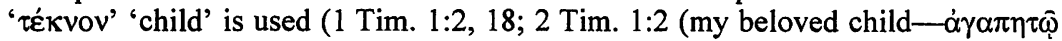
$\tau \varepsilon ́ \kappa v \omega) ; 2$ Tim. 2:1; Tit. 1:4). Interestingly viós is not used at all. In 1 Tim. 6:11 we read: 'But as for you, man of God (äv $\theta \rho \omega \pi \varepsilon \theta \varepsilon 0 \hat{)}) . .$. ' and similarly in 2 Tim.

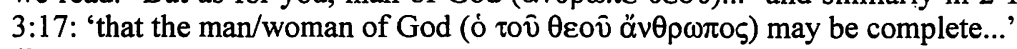

69 The term is also found in 1 Tim. $3: 15 ; 5: 16$. 
the Pastorals, with the latter being the most common, although other terms such as 'the elect', 'the household of God' are also used.

It is interesting to note that 'á $\delta \varepsilon \lambda \phi o ́ s$ ' can be seen to reflect 'horizontal' identity and points to a certain form or kind of human community. By contrast 'oi $\pi \mathrm{l \sigma \tau oí}$ ' can be seen to reflect 'vertical' identity, in the sense that it relates to God (we are 'the believing one'-by implication, believing in God), although in the Pastorals it also relates to a human religious activity of 'believing'. The two selfdesignations can thus be seen to be complementary, rather than in any sense 'competitors'.

In all of this, are we seeing simply the Pastor's understanding of what Christians should call themselves? Are these terms for selfdesignation simply the preferred terms of the Pastor and do they reflect only his perceptions? Or do we have grounds for suggesting that the Pastorals reflects the self-designations used by the addressees?

The Pastor clearly assumes, for example, that the audience will recognize themselves in the title 'the faithful ones'. This is most obvious in 1 Timothy 4:3; 5:16; 6:2 and Titus 1:6. Thus, when we read in Titus 1:6 that it is important that an elder's children 'are believers' or 'are faithful [to God]', I think it is fairly clear that $\pi$ $\sigma \tau$ có would have been a self-designation the readers would have owned. Otherwise there is a failure of communication. Further, the whole communication strategy of the Pastor is dependent on the readers identifying with these terms. That the author assumes that the audience will identity with 'the faithful ones' or 'the brothers and sisters' in the text, suggests this was a self-designation of the audience. There is no sense that these terms need to be justified, or explained or spelt out; they are entirely self-evident. We can argue therefore that the labels are self-designations used by the readers.

We also need to note the significance of the letter genre of the Pastorals. As letters, they are part of an on-going relationship between author and readers, who share some form of relationship. ${ }^{70}$ In writing a letter, we can suggest that an author would try to use terms that were recognised by the readers, terms with which they would be familiar and with which they would identify. We can assume this is the case, unless there are clear indications that the author is trying to introduce a new self-designation or is involved in polemic against the readers at a particular point. If this was the case, we would expect new or

70 This is true of pseudepigraphical letters too. 
polemical terms to be justified, or to be glossed or argued for in some clear way. If new terms were introduced without such additional discussion, we can suggest there would be a failure of communication on the part of the author, with the point the author seeks to make being lost on the readers. We have good grounds then for suggesting that the readers of the letters would have used 'brother and sister' and 'the faithful ones' as self-designations.

But we should also note that there may well be a tendentious edge in regard to the use of á $\delta \varepsilon \lambda \phi o ́ \varsigma$ language in the Pastorals. We have noted that 1 Timothy 6:2 suggests that slaves may have used $\dot{\delta} \delta \varepsilon \phi \phi o ́ \varsigma$ language differently from the Pastor. Although the Pastor uses

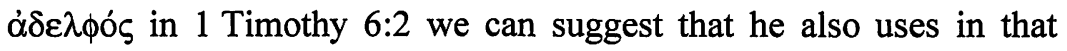
verse what he regards as preferable 'self-designations'- $\pi \iota \sigma \tau o$ i and (to a lesser degree since he only uses the term once more, of Timothy in 1 Tim. 1:2) d $\gamma \alpha \pi \pi \eta \tau o$; these are the terms he uses as he seeks to convince the slaves to not be 'disrespectful'. Certainly this verse suggests that the Pastor may not be entirely comfortable with ' $\alpha \dot{\delta} \varepsilon \lambda \phi o ́ s$ ' as a self-designation, or may be seeking to use it rarely. Further, we note that the group of widows of 1 Timothy 5:3-16 may

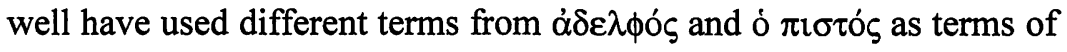
self-designation. They may well have used terms that were more egalitarian or reflected a different view of gender relations. By contrast, we have suggested that the Pastor uses the more egalitarian $\dot{\alpha} \delta \varepsilon \lambda \phi o ́ \varsigma$ less often because of his overall views about the nature of the church. However, there is no indication that the use of $\pi \iota \sigma \tau o$ o $\zeta$ has a tendentious edge to it, and given the significance of the $\pi \mathrm{l \sigma \tau}$ - word group in the Pauline tradition, we can suggest that it was used by the readers. 